\title{
Monetary Policy and Relative Prices in an Incomes Policy
}

\author{
by R. ALTON GILBERT
}

M

ONETARY policy will have an important influence on the effectiveness of the President's program for achieving price stability through direct controls of wages and prices. Lasting price stability requires a prudent course of monetary action.

The prospects for achieving price stability and full employment sooner with wage and price controls than with traditional monetary and fiscal actions alone depend on the ability of the wage and price controls to dampen expectations of inflation. Until expectations of inflation are substantially reduced, inflationary pres. sures will remain strong even though measured prices are constrained by government controls. The role of monetary policy is to keep the expansion of aggregate demand in line with the expansion in productive capacity. ${ }^{1}$ Given an excessive rate of monetary expansion, inflation will break into the open as soon as govemment controls are removed.

Besides the rate of monetary expansion, the viability of a system of price and wage controls may depend upon how closely the individual prices and wages fixed by administrative decisions correspond to the relative prices and wages that would exist without controls. A program for slowing the rate of inflation through direct controls is implemented through controls on wages and prices in individual industries, whereas under traditional stabilization policies the structure of wages and prices among industries is

\footnotetext{
1This statement about the role of monetary policy does not imply that price stability is the only objective of monetary policy. Full employment is also a policy objective. There is assumed to be no long-run trade off between the rate of inflation and the unemployment rate, and therefore, price stability and full employment can be achieved simultaneously if the rate of monetary expansion remains moderate. For a discussion of the inflation-memployment trade off, see Roger W. Spencer, "The Relation Between Prices and Employment: Two Views," this Review (March 1969), pp. 15-21.
}

determined by the price system. The rate of economic recovery will probably be infuenced by the impact the decisions of the pay board and price commission will have on the profit and labor shares of income. The allocation of output among industries will be influenced by the structure of wages and prices established by the control boards.

The role of monetary policy in an incomes policy of wage and price controls is analyzed in the first part of this article. Inflation is analyzed as a response to rapid monetary expansion. The prospects for achieving price stability through wage and price controls are discussed in terms of the monetary explanation for inflation. The prospects for economic expansion and an efficient allocation of resources under wage and price controls are discussed in the second section of the article. The issues analyzed are:

(a) the relation between economic recovery and the profit share of income, and

(b) the effects of individual wage and price decisions on the allocation of investment, employment, and ottput among industries.

\section{Monetary Policy and Inflation}

\section{Two Views on Intation and Controls}

The success that wage and price controls can be expected to have in dampening inflationary pressures depends upon the type of forces that initiate inflation and the reasons for persistent inflation when resources are no longer fully utilized. In one view, inlation is the result of increases in the market power of firms and labor over the prices they charge. Inflation due to rising market power is considered relatively insensitive to traditional monetary and fiscal policies. According to this view of the inflationary process, one means of dealing directly with inflationary forces is wage and price controls. 
An altemative explanation for inflation, the explanation followed in this article, is that the rate of inflation is determined by the tread of aggregate demand." The rate of increase in aggregate demand has been observed to be direcly related to the rate of growth of the money stock. With the economy at full employment, the rate of inflation is related to the rates of increase in aggregate demand and productive capacity. If aggregate demand increases faster than productive capacity, prices will rise to clear the markets for output.

After prices have been rising for some time due to excessive growth in aggregate demand, expectations of contimed inflation begin to affect negotiations for wages and prices. Even as the rate of output expansion declines because of a reduction in the rate of monetary expansion, prices may continue to rise due to the general expectation of inflation and the wage and price demands of the workers and firms who have not yet adjusted their wages and prices to the infation that has already occured. Inllationary pressures can be gradualy eliminated through moderate monetary expansion. With a moderate expansion of the money stock, aggregate demand does not rise fast enough to purchase full-employment output at the price level that is generally expected to exist. Wages and prices then gradually respond to the emergence of excess capacity.

\section{Slowing Inflation as an Aditsiment Process}

The emergence of inflation since 1965 can be analyzed in terms of the monetary explanation for inflation. From the second quarter of 1965 to the first quarter of 1969 , the money stock rose at a 5.6 per cent annual rate, compared to a 29 per cent rate in the previous 5 years. In the three and a half years from the second quarter of 1965 to the fourth quarter of 1969, total spending rose at about an 8 per cent annual rate, compared to a 6 per cent rate in the previous 5 years. The mate of growth in the money stock slowed in 1969 , rising at a 2.8 per cent annual rate from the first quarter to the fourth quarter of 1969 , compared to a 7.9 per cent growth in the previous year. Due to the lag in the effects of a change in the rate of money growth on spending, the growth rate of aggregate demand did not slow significantly until the fourth quarter of 1969.

\footnotetext{
2For a more thorough discussion of the market power and monetary expansion explanations for infation, see Keith M. Carlson, "Slowing in Money Growth: The Key to Success in Curbing Inflation," this Review (October 1971), pp. 2-5.

see Leonall C. Andersen and Keith M. Carlson, "A Monetarist Model for Economic Stabilization," this Review (Apri) 1970), pp. 7-2I.
}

The economy had reached full employment by 1965, so that increases in output were constrained by the growth of productive capacity, estimated at about 4 per cent per year. The general price level rose at about a 4 per cent annual rate from the second quarter of 1965 to the fourth quarter of 1969, compared with a 1.4 per cent rate of increase in the previous 5 years.

The money stock rose 5.1 per cent from the fourth quarter of 1969 to the fourth quarter of 1970. Due to restrictive monetary policy in 1969 and moderate monetary expansion in 1970 , spending rose 4.3 per cent during the $1969-70$ recession, compared with 6.5 per cent in the previous year. The general price level rose 5.7 per cent from the fourth quarter of 1969 to the fouth quarter of 1970 , compared with a 5.1 per cent increase during the previous year. The decline in the rate of economic activity in late 1969 failed to retard price increases because of cost pressures and the expectations of continued infation. The continued cost pressures resulted from demands for higher nominal wages by workers who had their real wages reduced by unanticipated inflation and the inflationary anticipations of workers gradualy formulated during the 1965-69 period.

Total spending in the economy has increased 7.7 per cent since the third quarter of 1970 , a significant acceleration from the 4.6 per cent rise in the previous year. The expansion in aggregate demand is partially a response to the rapid growth in the money stock in the first half of 1971. Due to the contimuing adjustments outlined above, however, most of the increase in total spending has been translated into price increases. The 4.7 per cent annual rate of increase in the general price level from the fourth quarter of 1970 to the second quarter of 1971 , compared with a 5.7 per cent increase in the previous year, shows the rate of inflation started to slow before the price freeze was initiated.

\section{The Cunent Pole of Monetury Polloy}

The success of the government's program for reducing inflationary pressures through direct controls on wages and prices is now discussed in terms of the monetary explanation for inflation. One condition for success of the program is a faster reduction in inflationary expectations than with traditional stabilization policies alone. If expectations of inflation can be reduced more quickly through wage and price controls, the economy can attain full employment and price stability sooner. The success of the New Economic Program also depends upon the rate of expansion in aggregate demand during the period of controls. If aggregate demand expands rapidly, consum- 


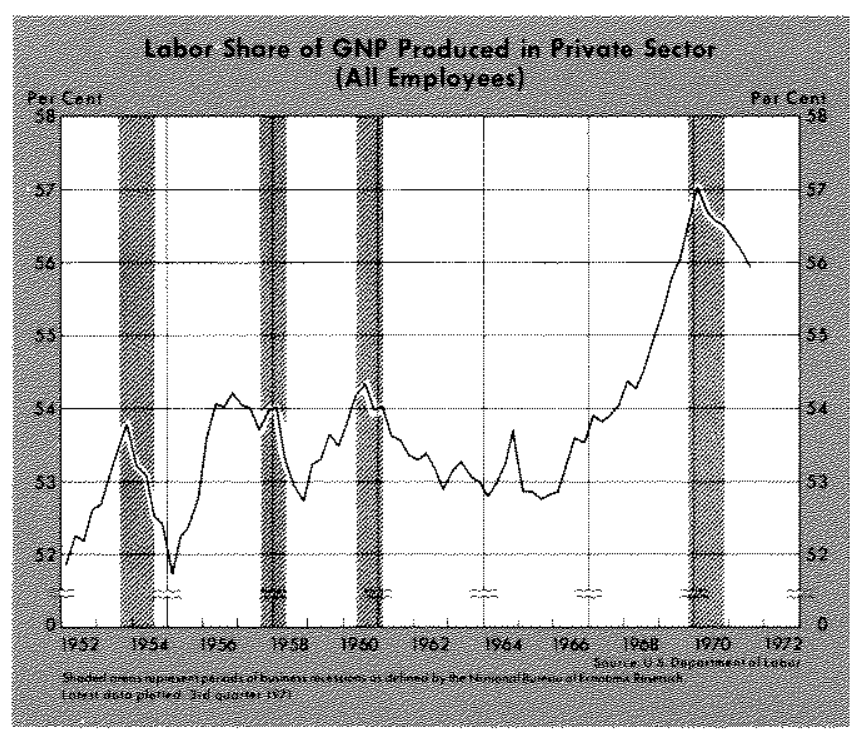

ers will demand more goods and services than firms wish to supply at the officially established prices. In such a situation, there would be pressures to evade the wage and price controls. Inflation could take such forms as quality deterioration and the development of black markets.

The role of monetary policy in controlling inflation under an incomes policy is the same as the role without an incomes policy - to keep the expansion of aggregate demand in line with the growth of potential output. If the relations observed in the past between changes in the money stock and aggregate demand continue to hold during the New Economic Program, the rate of increase in aggregate demand in the near future will be partially determined by past monetary actions. The rate of monetary expansion was rapid earlier this year. The money stock increased at a 10.5 per cent annual rate between December and June and has increased at a 1.6 per cent rate since June. With the lagged effect of changes in the money stock on total spending, the near term outlook is for expansion of total spending in the economy. Current monetary expansion will influence how rapid the expansion in aggregate demand will be in the near term.

\section{Incomes Policy and the Adjustment Process}

In attempting to deal with overall wage and price inflation through direct controls, the pay board and the price commission will influence the allocation of income between wages and profits and the relative wages and prices among industries. The allocation of income between wages and profits and relative wages and prices were in a process of change through the price system before the wage and price controls were

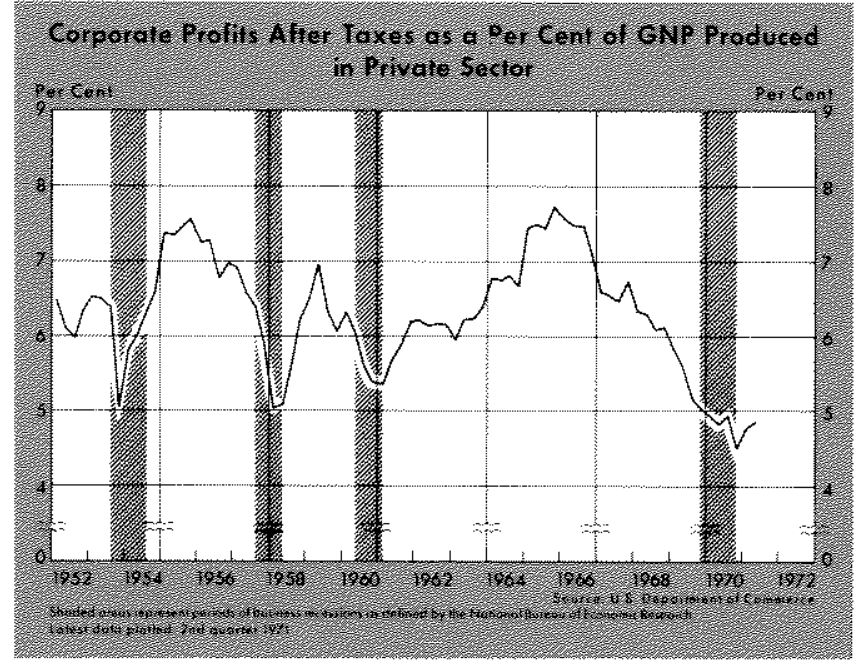

established. This allocation of income in the near future is likely to affect the rate of economic recovery through the effect the profit share has on investment. The degree to which changes in relative wages and prices among industries in the near future replicate the changes that would have occurred without wage and price controls will determine the degree to which resources will be allocated efficiently. Resources are allocated efficiently if they are used to produce the combination of goods and services that yields the greatest consumer satisfaction. An incomes policy that allows for changes in wages, prices, and income distribution consistent with the goals of overall price stability, economic recovery, and efficient allocation of resources will be difficult to design.

\section{The Allocation of Income}

One of the most prominent effects of the rapid economic expansion initiated in 1965 was a relatively large shift in income distribution of the private sector between labor income and returns to capital. The accompanying charts show after-tax corporate profits and compensation of employees as portions of total private product. Both the profit and labor shares of income have varied cyclically. The labor share tends to rise, and the profit share tends to fall during a period of economic expansion; the pattern is reversed during periods of recovery. ${ }^{4}$ Since 1965 labor compensation

\footnotetext{
4 For additional information on the cyclical pattern of the proft share of income, see Thor Hultgren, Cost, Prices, and Profuts: Their Gyclical Relations, (New York: National Bareau of Economic Research, 1965), pp. 78-97. There is an inconsistency in the tax treatment of the income shares used in this article in that profits are measured after taxes and labor compensation is measured before the taxes workers pay. Both corporate profits before taxes and corporate profits after taxes could be used to measure the profit concept in this article. Profits after taxes are used as a better estimate of the returns on investment. These two measures of profits as a fraction of income have similar cyclical patterns.
} 


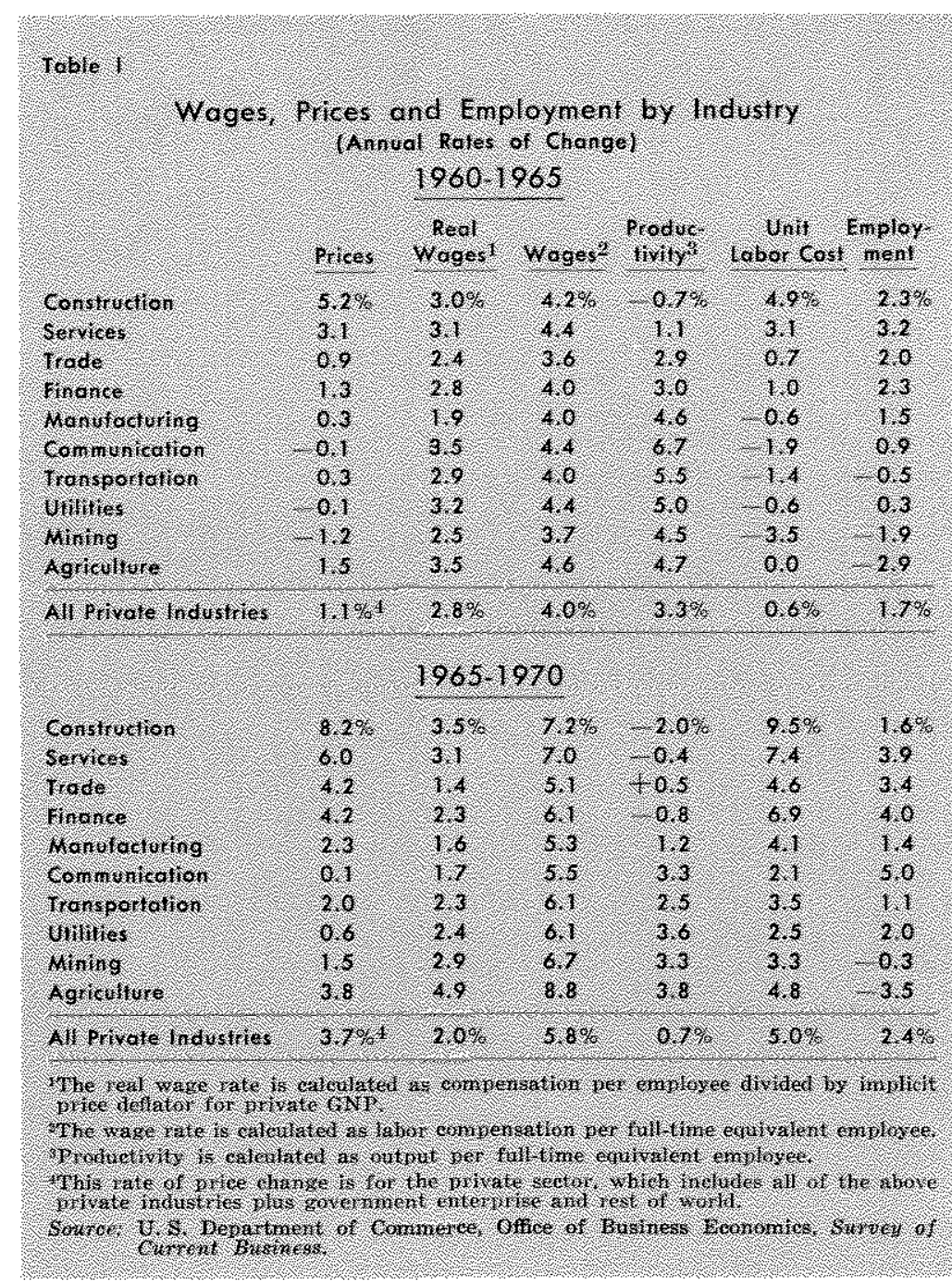

unit of output rose faster than prices during the $1965-70$ period, the share of the firms' revenues allocated to wages increased; a smaller share of revenue was left for other income categories.

If adjustments in the profit and wage shares are allowed to continue in accord with free market forces, and if historical patterns prevail, the profit share will tend to rise over the near term, and labor's share of income will tend to fall. With the economy monitored by wage and price boards, a rise in the profit share and a decline in the labor share in the near future may be interpreted by some observers as an undue concession to business. However, such a reallocation is to be expected during the recovery phase of a business cycle in an economy without controls on wages and prices. Any attempt to thwart such a change in income shares might hamper economic recovery.

\section{Income Shares by Industry}

The degree to which the labor share of output rose between 1965 and 1970 varied significantly among industries. As shown in Table I, the relations between the rate of change in prices and the rate of change in unit labor cost varied among industries during the 1965-70 period. The labor shares for individual industries in 1965 and 1970 are given in Table II. ${ }^{6}$ The rates of increase in

has accounted for a rapidly increasing portion of private income, rising from 52.8 per cent in 1965 to 56.7 per cent in 1970 . During the same period corporate profits after taxes changed little on average and accounted for a sharply decreasing portion of private income, from 7.5 per cent to less than 5 per cent.

The patterns of change in wages, prices, and productivity demonstrate the forces behind the recent decline in the profit share. Productivity increased slowly in the 1965.70 period relative to the rate of increase in previous years (see Table 1 ). With a rapid increase in wages, unit labor cost rose at a 5.0 per cent annual rate in private industries during the 196570 period while output prices rose at a 3.7 per cent rate in the private sector. ${ }^{5}$ Since labor cost per

EUnit labor cost equals labor compersation divided by physical output, or the labor cost per unit of output. labor shares were highest in the finance and com munication industries, the industries in which the rates of increase in employment were highest between 1965 and 1970 (see Table I). The rates of increase were lowest in the trade and agriculture industries. The annual rates of increase in the labor shares varied from 2.6 per cent for the finance industry to 0.4 per cent for the trade industry.

Some of the variation in the rates of change in labor shares may be due to differences among industries in the degrees to which the labor shares fuctuate over the business cycle. Trends in the labor shares vary among industries due to such factors as changes in the labor intensity of production. The rates of decrease in labor share can be expected to vary

6Only labor shares are given by industry and not profit shares since the profit shares that would correspond to the overall proft share in the accompanying chart are not available by industry. 


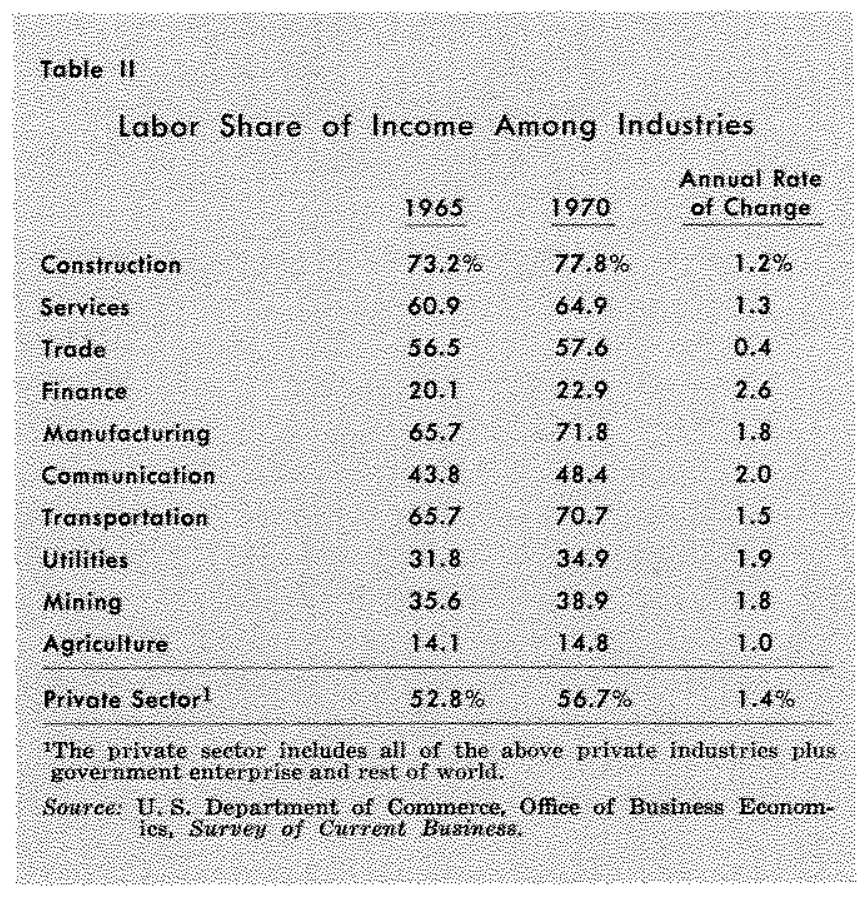

among industries during the current recovery because of the cyclical and trend effects if wages and prices change as they would without wage and price controls.

The allocation of investment expenditure is directly related to the relative rates of return on capital among industries. The control boards will influence this allocation to the extent that they influence the rates of increase in the profit shares among industries. An incomes policy that is neutral with respect to the allocation of investment seems difficult to design.

\section{Relative Prices and Wages}

Reallocations of output and employment among industries will be necessary for efficient production in the near future due to continuing changes in consumer tastes and technology. The wage and price boards should allow wages and prices to rise faster in some industries than in others to avoid excess demand for output in some industries and excess supply in others. As an indication of trends in the reallocation of output and employment among industries, Table III shows the distribution of output and employment among a ten industry breakdown of the private sector in selected years. Between 1952 and 1970 the shares of output produced in the agriculture, mining and construction industries declined most rapidly, while the shares in the communication, utilities, finance, and trade industries increased most rapidly. During the past 18 years, the shares of employment in the

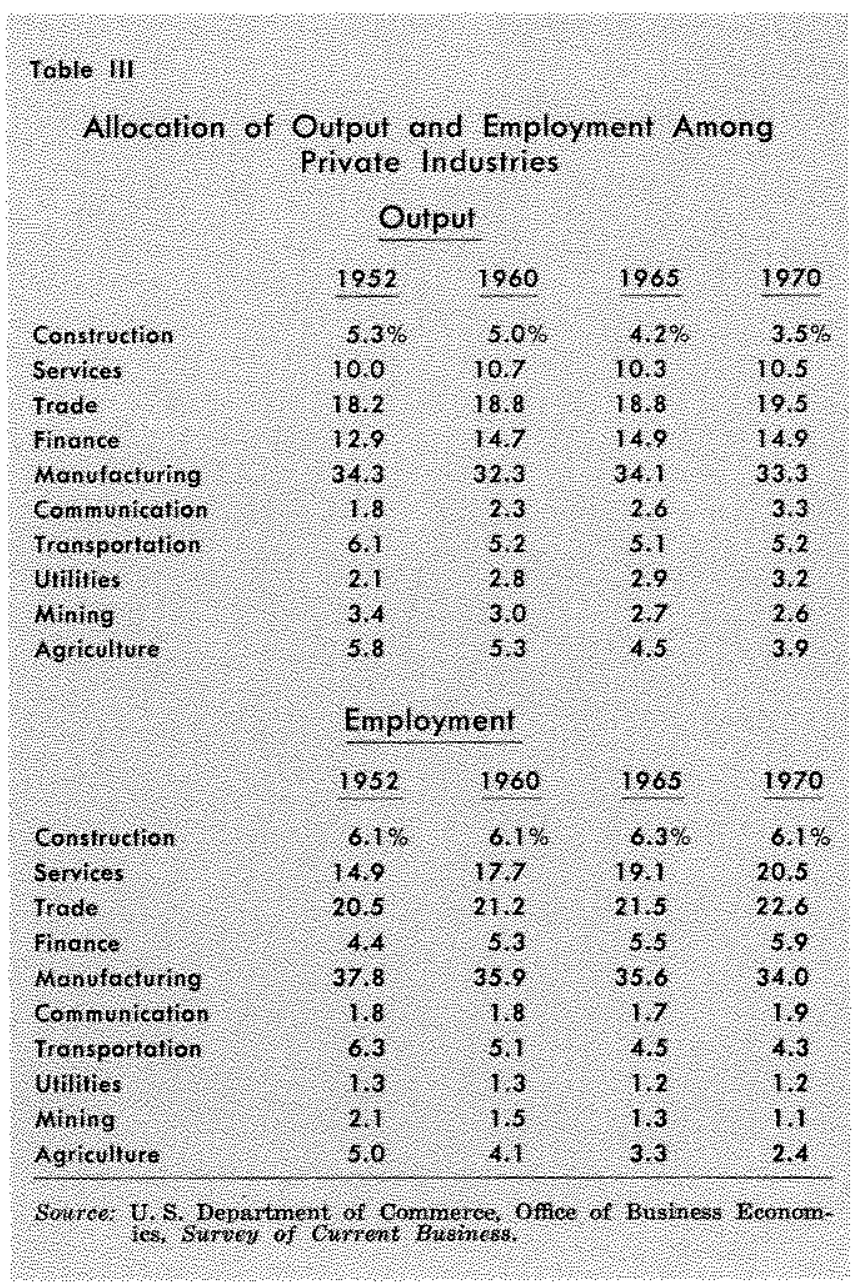

private sector increased most rapidly in the services and finance industries and decreased most rapidly in the mining and agriculture industries.

In a market economy this reallocation of output and employment is achieved through the price system. Uncontrolled wages and prices respond to such forces as changes in consumer taste and technology of production. ${ }^{7}$ Table I shows the rates of change in prices and real wages by industry for the periods 1960-65 and 1965-70 to give an indication of the degree of change in relative wages and prices among industries during the last ten years.

Firms and workers in different industries have been adjusting their prices and wages to inflation at dif-

\footnotetext{
Thelative wages and prices also respond to such forces as changes in the distribution of market power and the application of laws, such as the minimum wage law. An examination of Tables I and III indicates that wages did not necessarily rise fastest in the industries in which employment rose the fastest, and prices did not necessarily rise the fastest in industries in which output rose the fastest.
} 
ferent rates. Variation in the length and expiration date of labor and output contracts affects the degree to which expectations of inflation influence current transactions. Wages and prices tend to rise faster at those firms in which both the workers and management have higher than average expectations of inflation. For these reasons, the relative prices and wages that exist at any one point in the adjustment process of reducing the rate of inflation may not be consistent in the long run with the existing composition of demand for output among industries. Maintaining the relative wages and prices that existed immediately before the price and wage controls were initiated could slow an adjustment process necessary for an efficient allocation of resources, even if there were no change in the allocation of demand among industries. ${ }^{8}$

\footnotetext{
8The economy tends to be in a state of disequitibrum in the formation of relative wages and prices among industries and the allocation of resources in response to continuing changes in the allocation of demand among industries. As indicated above, there were additional reasons for disequilibrium at the time when price and wage controls were initiated. For a more thorough discussion of price formation in a changing economy, see Amen A. Alchian and William $R$. Allen, University Economics (Belmont: Wadsworth Publish ing Co., 1967), pp. 274-355.
}

\section{Conclusion}

The success of the President's New Economic Program in achieving full employment and price stability is dependent upon several important, and somewhat neglected, aspects:

1. An effective system of wage and price controls can reduce inflationary pressures faster than with traditional stabilization policies alone if it succeeds in eliminating expectations of inflation sooner than otherwise.

2. A moderate rate of monetary expansion is essential to the maintenance of a rate of increase in aggregate demand consistent with the dampening of fundamental inflationary pressures.

3. The rate of economic recovery will be influenced by the increase in the profit share of income allowed by the pay board and price commission.

Relative wages and prices among industries should be relatively free to change in response to changes in consumer tastes and technology if resources are to be allocated efficiently and the progress of economic recovery is not to be hampered.

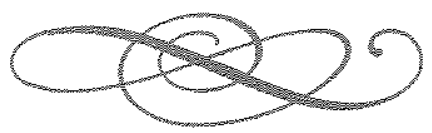

